\title{
THE USE OF MIND MAPPING ON IMPROVING STUDENTS' WRITING ABILITY AT TENTH GRADE OF SMAN 7 KOTA TANGERANG IN THE ACADEMIC YEAR OF 2018/2019
}

\author{
${ }^{1}$ Kamelia, ${ }^{2}$ Hiqma Nur Agustina, \& ${ }^{3}$ Imam Sudarmaji \\ 1, 2, 3 English Language Education, FKIP, Universitas Islam Syekh-Yusuf \\ Email:1kameliasurahmat1@gmail.com, 2higma@unis.ac.id, 3isudarmaji@unis.ac.id
}

\begin{abstract}
The objective of this study is to find the use of mind mapping on improving students' writing ability, especially for biographical recount text at the tenthgrade students of SMAN 7 Kota Tangerang in the academic year of 2018/2019.The sample of this study were 35 students. This study used quantitative method with pre - experimental design by using one group pre - test and post - test. The result of the research shows that there is a significant difference in student's writing ability between tenth grade students of SMAN 7 Kota Tangerang before and after taught using the mind mapping technique. It can be seen in the result of the study, the average pre - test score of experiment class students is 68.26 and the average post - test score of experiment class students is 85.40. It means that there is a significant difference in students' writing ability between tenth grade students of SMAN 7 Kota Tangerang before and after taught using the mind mapping technique. The research hypothesis is proven that using mind mapping technique in teaching writing especially in recount text makes the students' writing score higher.
\end{abstract}

Keywords: mind mapping technique, pre-experimental study, recount text, writing ability. 


\section{A. Introduction}

We need at least ability in writing, speaking, listening and reading in studying English. Being able to write English is very important, because as we know, it is being used in many aspects of global literature such as agreements in political and military, advertisement, business transaction, archiving, legal document, newspaper and especially in education. There are many kinds of writing such as academic writing, creative writing and personal writing. As language learners, the most important kind of writing that should be able to understand is academic writing.

Knowing mastery in writing is very important for learners especially who study at high school because the objective of writing is to produce a kind of writing text. Based on Curriculum 2013, students in senior high school have to be able to not only understand the nature of writing but also to produce certain various short functional texts. Moreover, the students can be facilitated by writing for better learning English. However according to the writer's observation when the writer did field experience program (PPL) at SMAN 7 Kota Tangerang found a fact that there were many students got difficulties to write a text or even they confused to find and develop their main idea into a readable text. The observation showed the students writing score from 36 students; 13 students got 68; 10 students got 70; 9 students got 73 and; 4 students got 75 . It means more than $60 \%$ of 36 students lack in writing. It becomes a problem when students difficult to process their ideas into a text, even sometimes they do not know what to do in the beginning of writing. That is why a technique is needed to help the students especially in writing. One of techniques which are available is the mind map technique.

Mind mapping is a technique which popular by Tonny Buzan in 1960 's that could help the students to write a text easier. Mind mapping is a diagram used to represent words, ideas, tasks, or other items linked to and arranged around a central key word or idea (Buzan, 1994:83). It helps students to collect their ideas and the words to write the text. Mind mapping can make students be more creative, because they can imagine their idea not only by writing the keywords but also by drawing the images in their minds. Mind mapping is the most effective and efficient way to enter, store and retrieve data from or to the brain. It is also stated by Bukhari (2016:58-77), Riswanto (2016:1-18) and Rajapriya \& Kumar (2017:975-981) related with the usage of this technique.

Those factors encouraged the writer to conduct the research on the use of mind mapping on improving students' writing ability at tenth grade of SMAN 7 Kota Tangerang. The result of this study is expected to become 
evidence that the technique of mind mapping can be one of proper technique in teaching writing.

\section{Study Literature}

\section{The Mind Mapping Technique}

\section{a. The Nature of the Mind Mapping}

Mind Mapping Technique is a concept invented by Buzan in 1960's. According to Buzan (2005:15), the concept of Mind Mapping is based on how the brain stores information. A credible research shows that the brain is a collection of nerve cell branches that can store the information. It has so many branches. The brain has the ability to store information that is very much from word to word even columns. To recall rapidly, the brain needs a way so that the parts that have been saved can be expressed back into diverse forms.

According to Buzan (1994:83), Mind Mapping is a storage system, with draw all data, and exceptional access to giant library, which actually exist in the amazing brain, because the Mind Mapping helps collate and store as much information as desired, and group with a natural way. Mind Mapping is a visual record that helps a person to distinguish words or ideas, often with colors and symbols. It generally takes a hierarchical or tree branch format, with branching into their subsections. Mind Mapping allows greater creativity when recording ideas and information, as well as enabling a note taker words related to visual representation. Mind Mapping has the method to facilitate someone to write and recall information that has been stored. It is an effort to develop the activity of thinking in all directions, capturing thoughts in different angles and develop divergent thinking and creative thinking.

Hence, the writer agreed with Panatda's definition of mind mapping technique in Siriphanich et al (2010:4). The teaching technique using mind mapping as a tool to represent students' understanding by using words, picture with colour and symbols in a tree branch format is really useful to develop students' ability in learning English.

\section{b. Benefits of Using the Mind Mapping to Teach Writing}

A mind mapping is a diagram used to represent words, ideas, tasks, or other items linked to and arranged around a central key word or idea. It helps students to collect their ideas and the words to write the text (Buzan, 2005:6). Mind mapping can make students be more creative, because they can imagine their idea not only by writing the keywords but also by drawing the images in their minds. 
Mind-mapping can help to make a new atmosphere in writing class. By using mind mapping, learning activity will be more interesting for the students (Widura, 2008). It can eliminate student's boredom because they can draw images on their minds and use many colors in making a draft before they write the text. They can also make a chronological text because they have to make their draft before they write. This strategy can make students be more active during the class and can improve students ability in writing.

Mind map is simply a visualization tool that helps to think and learn more proficiently. A mind map is a graphic diagram used to represent thoughts and ideas, tasks, or other items linked to a central key idea or theme. It is used to generate, visualize, structure and classify ideas. Mind maps are used as an aid in study, organization, problem solving, and decision making. Mind Mapping is the most effective, "brain-friendly" way for you to turn your unorganized, linear, fleeting ideas and thoughts into a structured, visual "map". Mind Map represents the best of both worlds by resembling the visual aspects of a flow chart and the organizational structure of an outline.

\section{c. How to Make Mind Mapping}

There are some preparations before making Mind Mapping, the students need some materials, namely blank paper, pens and colored pencils, and imagination. Buzan (2005:25), suggests there are seven steps to make Mind Mapping. Seven steps are as follows:

1. Putting the main idea in the center

Placing the main idea or topic in the middle of page will give maximum space for other ideas to radiate out from the center. It gives freedom to expand the ideas to any direction which is a perfect example of radiant thinking in action.

2. Using a picture or photo for the central idea Pictures have a strong impact on imagination and memory. It also pleases sight and keeps attention focused.

3. Using colors

The use of color is a very good memory marker. Colors on mind mapping are not only to engage the right brain active, but also to help the grouping information.

4. Connecting main branches to the center picture and connect the second and third branches to the first and second.

Trying to connect main branches to the center picture and connect the second and third branches to the first and second, and so on because the brain works according to the association.

5. Making a curve line connector, not a straight line. 
THE USE OF MIND MAPPING ON IMPROVING

STUDENTS' WRITING ABILITY AT TENTH GRADE

OF SMAN 7 KOTA TANGERANG IN THE ACADEMIC YEAR OF 2018/2019

Kamelia, Hiqma Nur Agustina, E Imam Sudarmaji

Draw a connector curve line in each branch to make it more attractive and beautiful.

6. Using one key word for each line

A single key word gives more energy and flexibility for mind mapping.

7. Using pictures

An image has a lot of meanings because it can replace a keyword or simply reinforce key words that have been written previously.

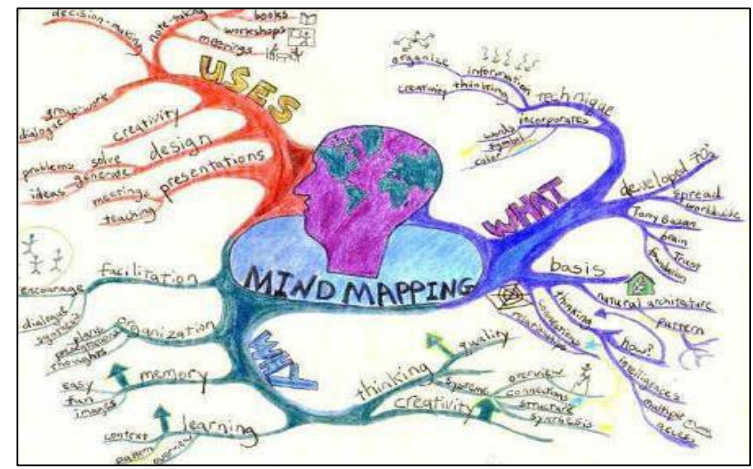

Figure 2.1: How to Make Mind Mapping

There were some previous research related the topic which is the use of Mind Mapping as the teaching strategy (Salem, 2017; Riswanto \& Putra, 2012; Yunus \& Chien, 2016; Suyanto, 2015; Tungprapa, 2015). Those researcher stated that through Mind Mapping could help the students to understand writing skill as well.

\section{B. Research Method}

\section{a. Place and Time of the Research}

This research was conducted at SMAN 7 Kota Tangerang on Jl. Perintis Kemerdekaan I No.2, Babakan, Kec. Tangerang, Kota Tangerang, Banten 15118. The research was began from January 2018 until August 2018 for collecting the data.

\section{b. The Method and The Research Design}

This research was used quantitative method which the form of data is numerical and it was analyzed using statistic calculations. The design of this research was pre - experimental design by using one group pre - test and post - test design. In this research, the group was given a pre-test before the experimental treatment and post-test after experimental treatment. The pretest and post-test are given to take the score of the students' achievement 
before and after being taught using mind mapping technique. Then both of the score were computed by using t-test to find out if there is significant influence of teaching reading comprehension by using mind mapping technique.

Table 2.1 The design of one-group pre-test post-test

\begin{tabular}{|ccc|}
\hline $\begin{array}{c}\text { Pre- } \\
\text { test }\end{array}$ & $\begin{array}{c}\text { Independent } \\
\text { Variable }\end{array}$ & $\begin{array}{c}\text { Post- } \\
\text { test }\end{array}$ \\
\hline Y1 & $\mathrm{X}$ & $\mathrm{Y} 2$ \\
\hline
\end{tabular}

\section{Explanation:}

$$
\begin{aligned}
& Y 1=\text { Pre-test } \\
& X=\text { Treatment } \\
& Y 2=\text { Post-tes }
\end{aligned}
$$

The procedures of experimental research that use One group pre-test posttest design:

1. Administering a pre-test with a purpose of measuring writing ability of tenth grade of SMAN 7 Kota Tangerang.

2. Applying the experimental treatment teaching writing by using mind mapping as a technique to the subject.

3. Administering a post - test with a purpose of measuring writing ability of tenth grade students at SMAN 7 Kota Tangerang.

Differences attributed to application of the experimental treatment are determined by comparing the pretest and posttest scores.

\section{c. Population, Sample and Technique Sampling}

The populations of this research were all the tenthgrade students at SMAN 7 Kota Tangerang in academic year 2018/2019, with X MIPA 2 class that consists of 35 students as samples.

In this research, the writer used non - probability sampling because the writer only need one class as experimental class. Non-probability sampling involves nonrandom procedures for selecting the members of the sample. In non-probability sampling, there is no assurance that every element in the population has a chance of being included. The major forms of nonprobability sampling are convenience sampling, purposive sampling, and quota sampling. In this type of sampling, items for the sample are selected deliberately by the writer (Ary et al, 2010:155). 
THE USE OF MIND MAPPING ON IMPROVING

STUDENTS' WRITING ABILITY AT TENTH GRADE

OF SMAN 7 KOTA TANGERANG IN THE ACADEMIC YEAR OF 2018/2019

Kamelia, Hiqma Nur Agustina, E Imam Sudarmaji

\section{Result and Discussion}

a. Description of Data

The research was done in SMAN 7 Kota Tangerang. The writer chose one class which was X MIPA 2 as the experiment class that consisted of 35 students. The writer used mind mapping technique in teaching writing at the class. It was done to find out whether there is a significant difference in students' writing ability between tenth grade students of SMAN 7 Kota Tangerang before and after taught using the mind mapping technique in academic year of 2018/2019

Based on the data of the test result of experiment class, the writer obtained the information which include the minimum score, maximum score, the average score (Mean), median and mode of experiment class as following:

\section{b. Data Result of Experiment Class}

The score of the students' writing skill of the experiment class before and after treatment using mind mapping technique shows that the pre - test and post - test score of the students writing skill was obtained through testing in the form of essay. The score ranged from 0 to 100. Based on the difference between the score pre - test and post - test, it was known the maximum score of pre - test was 77, minimum score was 56 with mean 68.26, median 68.00 and mode 67 . While the maximum score of post - test was 92 , minimum score was 80 with mean 85.40 , median 85.00 , and mode 85 . This calculation shows that students made a significant enhancement in their writing score.

From that result above, we can know that there is a differences between pre - test and post - test. Score in post - test histogram better than pre - test histogram. It means that mind mapping technique gives good advantages and gives the influence on student writing skill, because it can increase the students' score before and after taught using mind mapping technique.

\section{c. Testing of Hypothesis}

Based on the result of the research, the average pre-test score of experiment class students is 68.26 and the average post - test score of experiment class students is 85.40 , it indicated that the average score of the post - test is higher than pre - test score. Then by analyzing data through $t-$ test formula, it is known that the t-count is -11.363. In order to find the answer that the research is significance or not $t$-count compared with the $t$ table at significance value 0.05: $2=0.025$ (two tailed), degree of freedom is 34, 
it is obtained that $\mathrm{t}$-count is smaller than $\mathrm{t}$-table than the calculation of hypothesis can be seen on appendix.

The result of statistic calculation indicated that $-\mathrm{t}$-count $<-\mathrm{t}$-table $(-$ $11.363)<(-2.032)$ and sig $=0.000<0.05$, it can be concluded that Ho is rejected and Ha accepted. It means that there is a significant difference in students' writing ability between tenth grade students of SMAN 7 Kota Tangerang before and after taught using the mind mapping technique. The research hypothesis is proven that using mind mapping technique in teaching writing especially in recount text makes the students' writing score higher.

\section{Conclusion}

This research was conducted by using pre - experimental design which is aimed to find out whether mind mapping is effective to improve students' writing ability. The conclusion in this chapter is given based on the research finding and discussions. The conclusion presented as follows:

The first is it can be concluded that the mind mapping technique can improve the students' ability in writing biographical recount text also can increase the students' awareness that story characters and events are interrelated. It is supported by the result of this research that the hypothesis of this research is accepted.

The second is the students' writing post - test score higher than the pre - test score. It means that, there is improvement score in post-test data. In addition, between the result pre-test and post-test there are significant differences result, it is caused by the application of mind mapping technique as long the treatment time.

The last is the hypothesis of this research that is "There is a significant difference in students' writing ability between tenth grade students of SMAN 7 Kota Tangerang before and after taught using the mind mapping technique" can be acceptable, because the result of research show that $-t$ count <-ttable, based on the criteria of hypothesis if tcount less than ttable, it means that the hypothesis of research is acceptable. The research hypothesis is proven that using mind mapping technique in teaching writing especially in biographical recount text makes the students' writing score improved.

\section{References}

Bukhari, S. S. F. (2016). Mind Mapping Technique to Enhance EFL Writing Skill. International Journal of Linguistics and Communication, 4(1), 58-77. https://doi.org/10.15640.

Buzan, T. (2005). The Ultimate Book of Mind Maps, 542. Retrieved from http:/ / books.google.com/books?id=v4-D6Pu_9bAC\&pgis=1.

119 I Pelita - Jurnal Penelitian dan Karya Ilmiah 
Buzan, T., \& Buzan, B. (1994). How to Use Radiant Thinking to maximize Your Brain's Untapped Potential. New York: Dutton.

Rajapriya, M., \& Kumar, C. N. (2017). Effectiveness of mind mapping in Higher Education. International Journal of Civil Engineering and Technology, 8(4), 975-981. Retrieved from https:/ / www.scopus.com/inward/record.uri?eid=2-s2.0-

85019058142\&partnerID $=40 \& m d 5=4 b d b d 4 b 969 c 772 d 7 e 607 b e 1 c 7 b 7 b f$ $6 \mathrm{~d} 1$.

Riswanto. (2016). Improving The Students' Ability in Writing Report Genre Through Mind Mapping at Junior High School in Shouth Sumatera, Indonesia. International Journal of Social Sciences, 2(1), 1-18. https://doi.org/10.20319.

Riswanto, \& Putra, P. P. (2012). The Use of Mind Mapping Strategy in the Teaching of Writing at SMAN 3 Bengkulu, Indonesia. International Jurnal of Humanities and Science, 2(21), 60-68.

Salem, F. P. (2017). Improving Students' Writing Descriptive Text Using Mind Mapping Teaching Strategy of The Tenth Grade Students, 5(12), 147154. https://doi.org/10.5281/zenodo.1133832.

Suyanto, A. (2015). The Effectivenes Of Mind Mapping in Improving Students' Writing Skill Viewed From Their IQ, 2(2), 101-119. https://doi.org/10.15408/ijee.v2i2.3089.

Tungprapa, T. (2015). Effect of Using the Electronic Mind Map in the Educational Research Methodology Course for Master-Degree Students in the Faculty of Education. International Journal of Information and Education Technology, 5(11), 803-807. https://doi.org/10.7763/IJIET.2015.V5.615.

Yantu, Y. F. S. (n.d.). Developing Students' Ability in Writing Narrative Text by Using Story Map Technique, 1-16.

Yunus, M. M., \& Chien, C. H. (2016). The Use of Mind Mapping Strategy in Malaysian University English Test (MUET) Writing. Creative Education, 07(04), 619-626 https://doi.org/10.4236/ce.2016.74064. 